\title{
The interaction of housing condition and acute immobilization stress on the elevated plus-maze behaviors of protein-malnourished rats
} A.L. Françolin-Silva
and S.S. Almeida

\author{
Laboratório de Nutrição e Comportamento, Faculdade de Filosofia, \\ Ciências e Letras de Ribeirão Preto, Universidade de São Paulo, Ribeirão Preto, \\ SP, Brasil
}

\section{Correspondence \\ S.S. Almeida \\ Laboratório de Nutrição e \\ Comportamento, FFCLRP, USP \\ Avenida dos Bandeirantes, 3900 \\ 14040-901 Ribeirão Preto, SP \\ Brasil \\ Fax: +55-16-633-5015 \\ E-mail: sebasalm@usp.br}

Research supported by FAPESP (Nos. 95/9501-2 and 98/06309-1) and CNPq (Nos. 523325/95-9 and

479675/01-5)

Received June 2, 2003

Accepted March 12, 2004

\begin{abstract}
Protein malnutrition induces structural, neurochemical and functional alterations in the central nervous system, leading to behavioral alterations. In the present study, we used the elevated plus-maze (EPM) as a measure of anxiety to evaluate the interaction between acute immobilization and housing conditions on the behavior of malnourished rats. Pups ( 6 males and 2 females) were fed by Wistar lactating dams receiving a $6 \%$ (undernourished) or $16 \%$ (well-nourished) protein diet. After weaning, the animals continued to receive the same diets $a d$ libitum until 49 days of age when they started to receive a regular lab chow diet. From weaning to the end of the tests on day 70, the animals were housed under two different conditions, i.e., individual or in groups of three. On the 69th day, half of the animals were submitted to immobilization for $2 \mathrm{~h}$, while the other half were undisturbed, and both groups were tested $24 \mathrm{~h}$ later for $5 \mathrm{~min}$ in the EPM. Independent of other factors, protein malnutrition increased, while immobilization and social isolation per se decreased, EPM exploration. Analysis of the interaction of diet $v$ s immobilization $v s$ housing conditions showed that the increased EPM exploration presented by the malnourished group was reversed by acute immobilization in animals reared in groups but not in animals reared individually. The interaction between immobilization and housing conditions suggests that living for a long time in social isolation is sufficiently stressful to reduce the responses to another anxiogenic procedure (immobilization), while living in groups prompts the animals to react to acute stress. Thus, it is suggested that housing condition can modulate the effects of an anxiogenic procedure on behavioral responses of malnourished rats in the EPM.
\end{abstract}

Key words

- Postnatal protein malnutrition

- Elevated plus-maze

- Acute immobilization

- Housing conditions

- Anxiety 


\section{Introduction}

Protein or protein-calorie malnutrition imposed early in life is a well-known environmental factor that produces alterations in the brain. These alterations can affect morphological, neurochemical, neurophysiological, and functional aspects of the developing brain (1-8). Moreover, it is also well known that protein malnutrition during gestation and/or lactation can modify the behavior of rats in several animal models of anxiety. Malnourished animals submitted to experimental models of anxiety such as light-dark transition $(9,10)$, elevated plus-maze (EPM) $(11,12)$ and elevated T-maze (13) tests showed behavioral alterations that have been interpreted as lower anxiety levels and/or higher impulsiveness.

A study by our group showed that using an anxiogenic or stressful procedure (shortterm social isolation) reduces open-arm exploration by control animals but does not change the behavior of animals malnourished early in life (14). In contrast, social isolation for 1,2 or $24 \mathrm{~h}$ reduces exploration in the EPM (15). This suggests that the emotional alteration produced by early protein malnutrition is resistant to changes even when the animals are exposed to a stressful procedure before being tested in the EPM, thus showing a robust long-lasting emotional alteration produced by the nutritional deficit at the beginning of life.

In addition, immobilization is another classic stressful procedure used to alter exploratory behavior in the EPM. Animals submitted to immobilization stress present physiological, sensory or neurochemical alterations, as well as behavioral changes when submitted to the EPM, open-field, tail-flick and hole-board tests. Immobilization, when applied $24 \mathrm{~h}$ before the test, produced anxiogenic-like responses in the EPM (16-20) and in the open-field tests (21-23). In the EPM, immobilization for $2 \mathrm{~h}$ causes reduction in both the percent of entries and time spent in the open arms (16-20).

Since only long-term social isolation was not effective in reducing the increased exploration of the open arms in previously malnourished animals, we thought it would be useful to investigate the effects of two stressful procedures: social isolation followed by acute immobilization before the EPM test. Thus, our main objective was to determine if acute immobilization stress differentially affects open-arm exploration by wellnourished and malnourished animals reared individually or in groups from weaning to adulthood.

\section{Subjects and Methods}

Male Wistar rats from the animal colony of the Ribeirão Preto Campus, University of São Paulo, were used. Each litter was culled to 6 male and 2 female pups on the day of birth. The dams and the pups were housed in transparent plastic cages $(40 \times 33 \times 20 \mathrm{~cm})$ and assigned randomly to a $6 \%$ or a $16 \%$ protein ad libitum diet during the lactation phase (0-21 days). The diets have been described elsewhere (11). The protein-deficient diet contained approximately $8 \%$ casein ( $6 \%$ protein), $5 \%$ salt mixture, $1 \%$ vitamin mixture, $8 \%$ corn oil, $0.2 \%$ choline, and $77.8 \%$ corn starch $(\mathrm{w} / \mathrm{w})$. The regular protein diet contained approximately $20 \%$ casein (16\% protein), $60.8 \%$ corn starch and the same percentage of the other constituents as the protein-deficient diet. The two diets were supplemented with L-methionine $(2.0 \mathrm{~g} / \mathrm{kg}$ protein) since casein is deficient in this amino acid. Only male rats were used in this study. After weaning (21 days), the animals continued to receive the same diets until 49 days of age, when all animals started receiving a regular lab chow diet ad libitum until the end of the experiment. The animals were maintained on a 12:12-h light:dark cycle (lights on at 6:00 am) with room temperature kept at $23-25^{\circ} \mathrm{C}$, and with free access to water and food throughout the experiment. 
The behavioral tests were conducted during the light period (1:00 to 5:00 pm). The experiments were performed in compliance with the recommendations of the Brazilian Society of Neuroscience and Behavior (SBNeC), which are based on the US National Institutes of Health Guide for Care and Use of Laboratory Animals.

\section{Housing conditions}

After weaning, the animals submitted to both nutritional conditions were reared under two different housing conditions: individually in $30 \times 19 \times 14 \mathrm{~cm}$ plastic cages, or in groups of three animals per plastic cage $(40 \times 33 \times 17 \mathrm{~cm})$. Before the behavioral tests, animals in each housing condition were divided into immobilized and non-immobilized subjects generating four groups: nonimmobilized reared individually (NII, N = 67); non-immobilized reared in groups (NIG, $\mathrm{N}=22$ ); immobilized reared individually (II, $\mathrm{N}=42$ ), and immobilized reared in groups (IG, $\mathrm{N}=24$ ). The different number of animals was due to higher mortality of animals exposed to protein malnutrition, especially animals reared in groups.

\section{Apparatus}

The rats were placed on a wood base and wrapped with a hospital bandage secured with adhesive tape for the immobilization procedure. The wood bases were constructed according to the mean size of the animals on the day of immobilization (day 69): $24.5 \mathrm{x}$ $9.5 \times 1.5 \mathrm{~cm}$ for well-nourished animals and $19.5 \times 6.8 \times 1.5 \mathrm{~cm}$ for malnourished animals. The EPM was made of wood and consisted of two open arms $(50 \times 10 \mathrm{~cm})$ opposite to each other, crossed by two enclosed arms $(50 \times 10 \times 40 \mathrm{~cm})$ with an open roof (24). The maze was elevated $50 \mathrm{~cm}$ from the ground. Fluorescent ceiling lights $(2 \times 60 \mathrm{~W})$ provided the only illumination in the experimental room.

\section{Procedure}

On the 69th day, animals were placed on the wood base, hand-held and wrapped with the bandage except for the nose and the tail. The animals remained immobilized for $2 \mathrm{~h}$ before being returned to their home cages. The non-immobilized animals were also transported to the same room and kept undisturbed in their home cages during the same period or time ( $2 \mathrm{~h}$ ). Twenty-four hours later, the animals were tested in the EPM. For the EPM test the animals were placed individually in the center of the maze facing an enclosed arm and allowed to explore for 5 min. The test session was recorded with a vertically mounted video-camera (Sony, Tokyo, Japan) linked to a monitor and VCR in an adjacent room. The video-tapes were later analyzed by an experimenter, and the following behavioral categories were identified and recorded, as previously described (11,12,25-29): 1) the percent of open-arm entries (an arm entry defined as the rat having all four paws into an arm), 2) the duration of time spent in the open arms, 3) closed-arm entries, 4) attempts to enter open arms (entering an open arm with only the forepaws and returning to the central platform or closed arm), 5) latency to first open-arm entry (latency to enter an open arm timed from the start of the test), 6) rearing (rising on the hind paws), 7) head-dipping (scanning over the sides of the maze toward the floor), 8) stretch-attend posture (forward elongation of head and shoulders followed by retraction to the original position). The behavioral categories stretch-attend posture and head-dips have been previously described as risk-assessment behaviors $(11,25,26)$. The rearing category was included as a classical measure of exploration in a novel environment $(11,12)$. The other behavioral categories have been behaviorally and pharmacologically validated for rats $(24,27)$ and mice $(25,26,28,30)$ as reliable measures of fear/ anxiety levels. 


\section{Statistical analysis}

Data are reported as means \pm SEM and were analyzed by three-way (diet, housing condition and immobilization) analysis of variance (ANOVA). When appropriate, post hoc comparisons were made using the Newman-Keuls test. The level of significance was set at 0.05 .

\section{Results}

\section{Body weight}

On day 70 the malnourished animals weighed less than the well-nourished animals $(F(1,151)=738.60 ; \mathrm{P}<0.001)$, indicat-

Table 1. Body weight of rats at the age of 70 days when behavioral tests were carried out.

\begin{tabular}{lcc}
\hline & \multicolumn{1}{c}{ Individual } & Grouped \\
\hline Well-nourished & $374.9 \pm 6.8^{*+}$ & $405.7 \pm 10.7^{*}$ \\
Malnourished & $182.8 \pm 4.6^{+}$ & $155.6 \pm 6.6$
\end{tabular}

Data are reported as means \pm SEM for 86 wellnourished and 69 malnourished rats. Grouped animals were raised 3 to a cage.

${ }^{*} \mathrm{P}<0.05$ compared to malnourished animals reared in the same social condition (NewmanKeuls test). ${ }^{+} P<0.05$ compared to grouped animals reared in the same nutritional condition (Newman-Keuls test).

Figure 1. Number of entries (top) and duration of time spent (bottom) in the open arms of the elevated plus-maze by non-immobilized animals reared individually (NII) or in groups (NIG) and immobilized animals reared individually (II) or in groups (IG). Data are reported as mean \pm SEM percent of total number of entries or of total time for 17-57 rats in each group. ${ }^{*} P<0.05$ compared to IG in the same nutritional condition (NewmanKeuls test). ing that even a nutritional rehabilitation procedure did not restore the body weight deficits produced by early protein malnutrition. In addition, the weight of control and malnourished animals was differentially affected by housing conditions $(\mathrm{F}(1,151)=12.66 ; \mathrm{P}<$ $0.001)$. Control animals living in groups increased their body weights as compared with animals living individually, while malnourished animals living in groups decreased their body weights compared with animals living individually (Table 1).

\section{Behavioral measures}

As illustrated in Figure 1, malnourished animals showed increased percent of exploration of open-arms when compared to wellnourished animals, as indicated by a significant effect of diet on entries $(\mathrm{F}(1,147)=$ $21.02 ; \mathrm{P}<0.001)$ and duration of time spent in the open arms $(\mathrm{F}(1,147)=26.58 ; \mathrm{P}<$ $0.001)$. The immobilization procedure reduced the percent of entries $(\mathrm{F}(1,147)=$ $6.17 ; \mathrm{P}<0.05)$ and the duration of time spent in the open arms $(\mathrm{F}(1,147)=10.03 ; \mathrm{P}<$ 0.05). There was a significant main effect of housing conditions as indicated by an increased percent of entries $(\mathrm{F}(1,147)=27.68$; $\mathrm{P}<0.001)$ and the duration of time spent in the open arms $(\mathrm{F}(1,147)=56.01 ; \mathrm{P}<0.001)$ by animals raised in groups compared with individually housed animals. ANOVA also showed a significant diet $v s$ immobilization interaction in duration of time spent in the open arms $(\mathrm{F}(1,147)=9.19 ; \mathrm{P}<0.05)$, showing that malnourished immobilized animals decreased the duration of time spent in the open arms in relation to non-immobilized animals, as compared with no effects on well-nourished animals. Furthermore, ANOVA indicated a significant immobilization $v s$ housing interaction in duration of time spent in the open arms $(\mathrm{F}(1,147)=5.17$; $\mathrm{P}<0.05)$, indicating that the duration of time spent in the open arms was decreased by the immobilization procedure in grouped ani- 
mals as compared with no effect in the animals reared individually. Finally, ANOVA indicated a significant diet $v s$ immobilization $v s$ housing condition interaction in the duration of time spent in the open arms $(\mathrm{F}(1,147)=12.36 ; \mathrm{P}<0.001)$. Only the malnourished animals in the grouped condition had their performance significantly affected by the immobilization procedure $(\mathrm{P}<$ $0.05)$. They presented a decreased duration of time spent in the open arms.

As illustrated in Figure 2, closed-arm entries were not affected by any of the variables studied. However, early protein malnutrition decreased the attempts to enter open arms $(\mathrm{F}(1,147)=9.06 ; \mathrm{P}<0.05)$ as well as the latency to first entry into the open arms $(\mathrm{F}(1,147)=8.89 ; \mathrm{P}<0.05)$. Furthermore, rearing the animals in groups reduced their attempts to enter open arms $(\mathrm{F}(1,147)=$ $8.43 ; \mathrm{P}<0.05)$ and the latency to first entry into open arms $(\mathrm{F}(1,147)=19.01 ; \mathrm{P}<0.001)$ compared to animals reared individually.

As illustrated in Figure 3, rearings were not affected by any factor studied. However, early malnutrition produced an increase in the head-dips as indicated by a significant main effect of diet $(\mathrm{F}(1,147)=8.47 ; \mathrm{P}<$ $0.05)$. Animals in the immobilized groups showed a decrease in head-dip frequencies as indicated by a significant main effect of the immobilization procedure $(\mathrm{F}(1,147)=$ 5.56; $\mathrm{P}<0.05)$, and the animals reared in groups showed an increase in head-dip frequencies as indicated by a significant main effect of housing condition $(\mathrm{F}(1,147)=31.08$; $\mathrm{P}<0.001)$. Furthermore, ANOVA indicated a significant interaction between immobilization and housing conditions $(\mathrm{F}(1,147)=$ $4.40 ; \mathrm{P}<0.05)$, indicating that in the nonimmobilized condition animals living in groups had higher head-dip frequencies compared to the same condition in the immobilized condition. In addition, ANOVA also indicated a significant diet $v s$ immobilization $v s$ housing condition interaction $(\mathrm{F}(1,147)=4.99 ; \mathrm{P}<0.05)$. Only malnour-
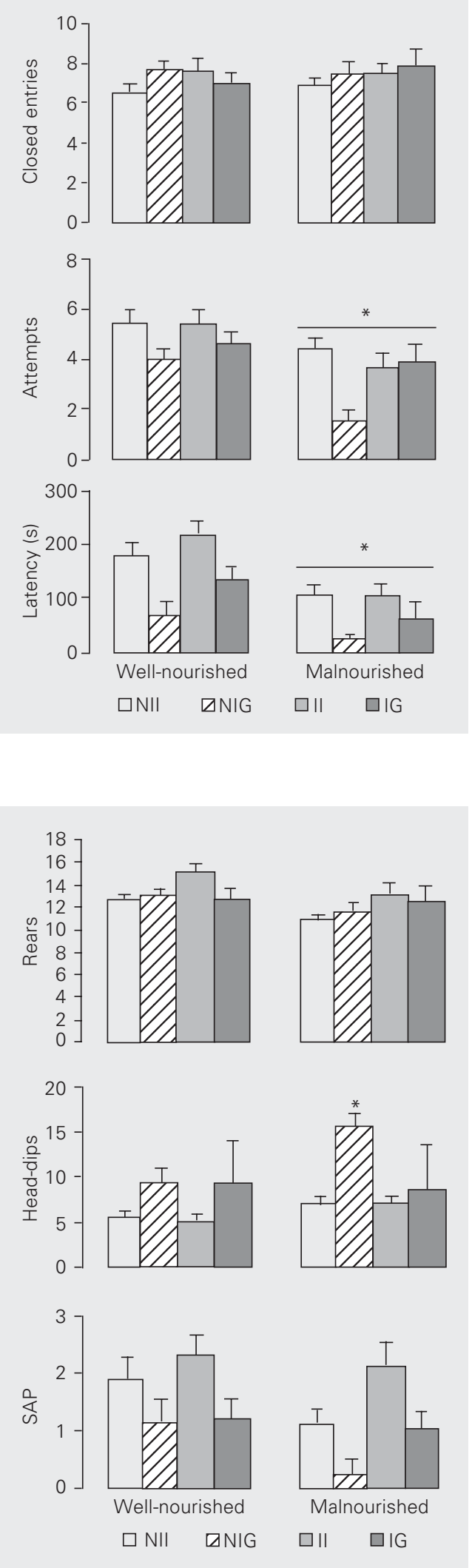

Figure 2. Number of closed-arm entries (top), attempts to enter into open arms (middle) and latencies for the first open-arm entry (bottom) by non-immobilized animals reared individually (NII) or in groups (NIG) and immobilized animals reared individually (II) or in groups (IG). Data are reported as means \pm SEM for $17-57$ rats in each group. ${ }^{*} \mathrm{P}<0.05$ compared to well-nourished animals (Newman-Keuls test).

Figure 3. Number of rears (top), head-dips (middle) and stretchattend postures (SAP, bottom) by non-immobilized animals reared individually (NII) or in groups (NIG) and immobilized animals reared individually (II) or in groups (IG). Data are reported as means \pm SEM for $17-57$ rats in each group. ${ }^{*} P<0.05$ compared to IG in the same nutritional condition (Newman-Keuls test) 
ished animals in the grouped housing condition had their performance significantly affected by the immobilization procedure. There was a decrease in head-dip frequency. Finally, ANOVA revealed that animals reared in groups showed a decrease in stretch-attend posture frequency as indicated by a significant effect of housing condition $(\mathrm{F}(1,147)=9.68 ; \mathrm{P}<0.05)$.

\section{Discussion}

The results presented here show that early postnatal protein malnutrition significantly reduced the body weight of the animals, as previously reported by our group (10,31-34) and in the literature (35-38). In addition, social stimulation (rearing animals in groups) increased the body weight of well-nourished animals while reducing the body weight of malnourished animals. It is not easy to provide a satisfactory explanation for this result. However, it is possible that malnourished animals spent much more energy on competition for food than well-nourished animals when living in groups.

Early postnatal protein malnutrition also produced a lower anxiety level according to the EPM test, as indicated by high frequency of entries and duration of time spent in the open arms, high frequencies of head-dips, low frequencies of attempts to enter open arms, and low latencies to the first open-arm entry. Stretch-attend posture was not affected by malnutrition. The lower anxiety of malnourished animals has been described in our studies on both pre- $(12,13)$ and post-natal protein malnutrition $(10,29,32)$, suggesting that an early nutritional deficit changes the responsiveness of rats in pain-free animal models of anxiety. This result cannot be attributed to changes in locomotor activity or environmental exploration produced by protein malnutrition since the frequency of closed-arm entries and rearings was not affected by any of the factors studied (diet, immobilization or housing condition).
Both immobilization and social isolation stress, the two other independent variables, produced changes consistent with other studies (15-20). Thus, acute immobilization and housing condition reduced all the classical behavioral categories investigated in the EPM (frequency and duration of open-arm exploration). It was also shown that housing animals individually was more effective than acute immobilization in producing increased anxiety in the EPM, as observed in the other behavioral categories, since housing condition affected all behaviors except closedarm entries and rearings (behaviors more related to locomotor activity and exploration), while immobilization did not affect closed-arm entries, attempts to enter open arms, latency to first open-arm entry, rearings, or stretch-attend posture. Thus, while both factors increased anxiety it appears that social condition has a stronger effect on riskassessment behaviors in the EPM compared to acute immobilization stress.

The new information reported in the present study concerns the interaction of protein malnutrition and the other two variables, i.e., housing and immobilization. Thus, while in the non-immobilized condition the malnourished animals showed a higher frequency of exploration of open arms compared to well-nourished animals, the immobilization procedure reduced the exploration of open arms (\% time in the open arms and headdips) of malnourished animals to values similar to those presented by well-nourished animals. These data suggest that the introduction of an acute stress was efficient in reversing differences due to diet in the level of EPM exploration. Moreover, this influence was more evident for animals reared in groups than for animals living individually, leading to a significant diet $v s$ immobilization $v s$ housing condition interaction. These data also showed that the anxiogenic effects of acute immobilization, responsible for a higher reduction in EPM exploration in malnourished than in well-nourished rats, depended 
on housing condition, as indicated by a significant housing condition $v s$ immobilization interaction. Thus, it seems clear that the effectiveness of an acute stress depends on the housing conditions of the animals. It appears that living individually for a long time (from weaning to adult age) is sufficiently stressful to reduce the responses to a different stressful procedure (immobilization). However, living in a group prompts an animal to exhibit a greater reaction to an acute stress procedure. This result contrasts with our previous report showing that shortterm social isolation reduced EPM exploration in well-nourished rats but did not affect early postnatal protein-malnourished rats (14). Thus, we suggest that housing condition is an important factor to consider when choosing stressful intervention to study behavioral responses in malnourished animals.

\section{References}

1. Almeida SS, Tonkiss J \& Galler JR (1996). Malnutrition and reactivity to drugs acting in the central nervous system. Neuroscience and Biobehavioral Reviews, 20: 389-402.

2. Bedi KS (1987). Lasting neuroanatomical changes following undernutrition during early life. In: Dobbing J (Editor), Early Nutrition and Later Achievement. Academic Press, London, UK.

3. Bedi KS (1991). Effects of undernutrition during early life on granule cell numbers in the rat dentate gyrus. Journal of Comparative Neurology, 311: 425-433.

4. Tonkiss J, Galler JR, Morgane PJ, Bronzino JD \& Austin-LaFrance RJ (1993). Prenatal protein malnutrition and postnatal brain function. Annals of the New York Academy of Sciences, 678: 215-227.

5. Morgane PJ, Austin-LaFrance RJ, Bronzino JD, Tonkiss J, DíazCintra S, Cintra L, Kemper T \& Galler JR (1993). Prenatal malnutrition and development of the brain. Neuroscience and Biobehavioral Reviews, 17: 91-128.

6. Morgane PJ, Austin-LaFrance RJ, Tonkiss J \& Galler JR (1992). Malnutrition and the developing central nervous system. In: Isaacson RL \& Jensen KF (Editors), The Vulnerable Brain Environmental Risks. Vol. I. Malnutrition and Hazard Assessment. Plenum Press, New York

7. Morgane PJ, Miller M, Kemper T, Stern W, Forbes W, Hall T, Bronzino J, Kissane J, Hawrylewicz E \& Resnick O (1978). The effects of protein malnutrition on the developing central nervous system of the rat. Neuroscience and Biobehavioral Reviews, 2: 137230.

8. Dobbing J (1987). Early Nutrition and Later Achievement. Academic Press, London, UK.

9. Brioni JD \& Orsingher OA (1988). Decreased reactivity to the anticonflict effect of diazepam in perinatally undernourished rats. Physiology and Behavior, 44: 193-198.

10. Santuci LB, Daud MM, Almeida SS \& De Oliveira LM (1994). Effects of early protein malnutrition and environmental stimulation upon reactivity to diazepam in two animal models of anxiety. Pharmacology, Biochemistry and Behavior, 49: 393-398.

11. Almeida SS, Garcia RA, Cibien MMR, De Araújo M, Moreira GMS \& De Oliveira LM (1994). The ontogeny of exploratory behaviors in early malnourished rats exposed to elevated plus-maze test. Psychobiology, 22: 283-288.

12. Almeida SS, Tonkiss J \& Galler JR (1996). Prenatal protein malnutrition behavior of female rats in elevated plus-maze. Physiology and Behavior, 60: 675-680.

13. Almeida SS, Tonkiss J \& Galler JR (1996). Prenatal protein malnutri- tion affects avoidance but not escape behavior in the elevated $\mathrm{T}$ maze test. Physiology and Behavior, 60: 191-195.

14. Almeida SS, Araujo M, Moreira GMS, Paiva RVF \& De Oliveira LM (1998). Short-term social isolation does not reduce elevated plusmaze exploration in early protein malnourished rats. Nutritional Neuroscience, 1: 103-110.

15. Maisonnette S, Morato S \& Brandão ML (1993). Role of resocialization and of 5-HT1A receptor activation on the anxiogenic effects induced by social isolation in the elevated plus-maze test. Physiology and Behavior, 54: 753-758.

16. Padovan CM \& Guimarães FS (1993). Attenuation of behavioral consequences of immobilization stress by intrahippocampal microinjection of zimelidine. Brazilian Journal of Medical and Biological Research, 26: 1085-1089.

17. Chaouloff F, Baudrie V \& Coupry I (1994). Effects of chlorisondamine and restraint on cortical $\left({ }^{3} \mathrm{H}\right)$-ketanserin binding, $5 \mathrm{HT}_{2} \mathrm{~A}$ receptormediated head shakes, behaviours in models of anxiety. Neuropharmacology, 33: 449-456.

18. Netto SM \& Guimarães FS (1996). Role of hippocampal 5-HT1A receptors on the elevated plus maze exploration after a single restraint experience. Behavioural Brain Research, 77: 215-218.

19. Martijena ID, Calvo N, Volosin M \& Molina VA (1997). Prior exposure to a brief restraint session facilitates the occurrence of fear in response to conflict situation: behavioral and neurochemical correlates. Brain Research, 752: 136-142.

20. Mendonça FH \& Guimarães FS (1998). Intra-hippocampal administration of cycloheximide attenuates the restraint-induced exploratory deficit of an elevated plus maze. Behavioural Brain Research, 91: 207-211.

21. Kennett GA, Dickinson SL \& Curzon G (1985). Enhancement of some 5-HT-dependent behavioural responses following repeated immobilization in rats. Brain Research, 330: 253-263.

22. Kennett GA, Dickinson SL \& Curzon G (1985). Central serotonergic responses and behavioural adaptation to repeated immobilisation: the effect of the corticosterone synthesis inhibitor metyrapone. European Journal of Pharmacology, 119: 143-152.

23. Kennett GA, Dourish CT \& Curzon G (1987). Antidepressant-like action of 5-HT-1A agonists and conventional antidepressants in an animal model of depression. European Journal of Pharmacology, 134: 265-274.

24. Pellow S, Chopin P, File S \& Briley M (1985). Validation of openclosed arm entries in an elevated plus-maze as a measure of anxiety in the rat. Journal of Neuroscience Methods, 14: 149-167. 
25. Rodgers RJ \& Cole JC (1993). Anxiety enhancement in the murine elevated plus-maze by immediate prior exposure to social stressors. Physiology and Behavior, 53: 383-388.

26. Rodgers RJ \& Cole JC (1993). Influence of social isolation, gender, strain, and prior novelty on plus-maze behavior in mice. Physiology and Behavior, 54: 729-736.

27. Cruz APM, Frei F \& Graeff FG (1994). Ethopharmacological analysis of rat behavior on the elevated plus-maze. Pharmacology, Biochemistry and Behavior, 49: 171-176.

28. Cole JC \& Rodgers RJ (1994). Ethological evaluation of the effects of acute and chronic buspirone treatment in the murine elevated plus-maze: comparison with haloperidol. Psychopharmacology, 114: 288-296.

29. Almeida SS, Garcia RA \& De Oliveira LM (1993). Effects of early protein malnutrition on repeated testing upon locomotor and exploratory behaviors in the elevated plus-maze. Physiology and Behavior, 54: 749-752.

30. Lister RG (1987). The use of a plus-maze to measure anxiety in the mouse. Psychopharmacology, 92: 180-185.

31. Almeida SS, De Oliveira LM \& Graeff FG (1990). Decreased reactivity to anxiolytics caused by early protein malnutrition in rats. Pharmacology, Biochemistry and Behavior, 36: 997-1000.

32. Almeida SS, De Oliveira LM \& Graeff FG (1991). Early life protein malnutrition changes exploration of elevated plus-maze and reactivity to anxiolytics. Psychopharmacology, 103: 513-518.

33. Almeida SS, Soares EG, Bichuette MZ, Graeff FG \& De Oliveira LM (1992). Effects of early postnatal malnutrition and chlordiazepoxide on experimental aversive situations. Physiology and Behavior, 51 : 1195-1199.

34. Rocinholi LF, Almeida SS \& De Oliveira LM (1997). Response threshold to aversive stimuli in stimulated early protein-malnourished rats. Brazilian Journal of Medical and Biological Research, 30: 413-417.

35. Finger S \& Green L (1983). Early undernutrition and later hippocampal damage: I. DRL performance in rats. Nutrition and Behavior, 1: 195-206.

36. Bedi KS (1994). Undernutrition of rats during early life does not affect the number of cortical neurons. Journal of Comparative Neurology, 342: 596-602.

37. Peeling A \& Smart JL (1994). Successful prediction of immediate effects of undernutrition throughout the brain growth spurt on capillary and synapse-to-neuron ratio of cerebral cortex in rats. Metabolic Brain Disease, 9: 81-95.

38. Rocha JBT \& Mello CF (1994). Handling during suckling alters rat behaviour but does not reverse the deleterious effects of undernutrition on naltrexone-induced inhibition of exploratory activity. International Journal for Vitamin and Nutrition Research, 64: 152-156. 